УДК 343.98:351.741

DOI https://doi.org/10.32849/2663-5313/2021.2.50

\title{
Федір Сокиран,
}

канд. юрид. наук, дочент,

професор кафедри криміналістики та судової медицини

Начіональної академії внутрішніх справ Украӥни

\section{Свген Войтович,}

ад'юнкт кафедри криміналістики та судової медииини

Начіональної академії внутрішніх справ Украӥни

\section{ВИКОРИСТАННЯ СПЕЦІАЛЬНИХ ЗНАНЬ ПІД ЧАС РОЗСЛІДУВАННЯ НАСИЛЬНИЦЬКОГО ЗНИКНЕННЯ ЛЮДИНИ}

У статті з'ясовано, що використання спеціальних знань під час розслідування насильницького зникнення людини здійснюється у формах залучення спечіаліста до проведення слідчих (розшукових) дій, залучення спеціаліста до проведення негласних слідчих (розшукових) дій, залучення експерта і проведення експертизи, надання консультачій спечіалістом. Визначено, що важливою формою застосування спечіальних знань у кримінальних провадженнях, розпочатих за фактом насильницького зникнення людини, є залучення експерта і проведення експертизи. Особливе місце в розслідуванні таких злочинів належить дактилоскопічній експертизі. Однак дочільно активніше застосовувати генноідентифікаиійні експертизи, головним завданням яких є ідентифікація конкретної особи на основі генетичної інформачії, що є в біологічних частинках - шматочках шкіри, а також у рідинах слині, крові, поту, й експертизи телекомунікаиійних систем і засобів, що пов'язано з необхідністю дослідження інформаиії, яка міститься в пам'яті мобільних телефонів, смартфонів, зокрема SIMкартки (потерпілого або підозрюваного). Наголошено, що для призначення молекулярно-генетичної експертизи до експертної установи надають вилучені зразки біологічного походження; зразки слідів біологічного походження осіб, що проходять у справі, для порівняння (кров, слина). Вилучення зразків біологічного походження проводять за визначеною КПК України процедурою. Зроблено висновок, що в умовах набуття злочинною діяльністю нових та особливо небезпечних форм, з одного боку, і реформування органів кримінальної юстииї, адаптаиї законодавства України до європейського - з іншого, актуальним є питання аналізу теоретичного підгрунтя й вивчення судово-експертної практики задля виявлення проблемних питань, які існують у сфері експертного забезпечення правосуддя, і на підставі ивого - розроблення шляхів вирішення иих проблем. Судова експертиза все більше стає затребуваною під час досудового розслідування кримінальних проваджень про насильницьке зникненнялюдини.

Ключові слова: насильницьке зникнення, людина, досудове розслідування, спеціальні знання, спеціаліст, експерт, експертиза.

Постановка проблеми. З'ясовуючи особливості процесуальної регламентації використання спеціальних знань під час розслідування насильницького зникнення людини, варто передусім проаналізувати положення Кримінального процесуального кодексу (далі - КПК) України [1]. Варто зазначити, що сьогодні питання участі спеціаліста в проведенні слідчих (розшукових) дій (далі - СРД) фрагментарно досліджені в роботах вітчизняних і зарубіжних учених. Роботи, присвячені методиці розслідування злочинів (М.В. Даньшин, В.В. Плотнікова, В.Д. Пристанкова, М.В. Тузлукової,) у частині проведення СРД, відображають окремі питання участі спеціаліста в розслідуванні викрадення людини. Однак питання, що стосуються використання спеціальних знань у формі участі спеціаліста при розслідуванні насильницького зникнення людини залишилися поза увагою науковців.

Метою статті є аналіз проблем використання спеціальних знань під час розслідування насильницького зникнення людини.

Виклад основного матеріалу. Спеціаліст у кримінальному процесі має статус учасника кримінального провадження з відповідними правами й обов'язками (згідно 3 п. 25 ст. 3 КПК України) [1].

У вітчизняному кримінальному процесі фігурує два учасники кримінального 
провадження, що володіють спеціальними знаннями, - експерт (ст. 69 КПК України) і спеціаліст (ст. 71 КПК України) [112].

Зокрема, згідно зі ст. 69 КПК України, експертом у кримінальному провадженні є особа, яка володіє науковими, технічними або іншими спечіальними знаннями, має право відповідно до Закону України «Про судову експертизу» [2] на проведення експертизи та якій доручено провести дослідження об'єктів, явищ і процесів, що містять відомості про обставини вчинення кримінального правопорушення, дати висновок 3 питань, які виникають під час кримінального провадження і стосуються сфери iї знань [1].

Відповідно до ст. 71 КПК України, спеціалістом у кримінальному провадженні є особа, яка володіє спеціальними знаннями й навичками застосування технічних або інших засобів, може надавати консультації під час досудового розслідування й судового розгляду з питань, що потребують відповідних спеціальних знань і навичок. Спеціаліст може бути залучений для надання безпосередньої технічної допомоги (фотографування, складення схем, планів, креслень, відбір зразків для проведення експертизи тощо) сторонами кримінального провадження під час досудового розслідування та судом під час судового розгляду. Сторони кримінального провадження мають право під час судового розгляду заявляти клопотання про залучення спеціаліста або використання його пояснень і допомоги [1].

Порівнюючи регламентацію процесуального статусу експерта та спеціаліста, варто акцентувати на деяких відмінностях. Так, експертом є особа, «яка володіє науковими, технічними або іншими спеціальними знаннями...». Водночас спеціалістом є особа, яка «володіє спеціальними знаннями та навичками застосування технічних або інших засобів...». Поряд з іншими відмінностями, які об'єктивно обумовлені компетентністю та виконуваними завданнями, уважаємо не цілком точним підхід законодавця до визначення спеціальних знань, якими володіють ці учасники кримінального провадження. Стосовно експерта йдеться про «наукові, технічні або інші спеціальні знання», а щодо спеціаліста - «спеціальні знання та навички застосування технічних та інших засобів». За такого формулювання складається враження, що спеціаліст - це лише технічний помічник слідчого. Однак спеціальні знання, про що влучно зазначили В.К. Лисиченко та В.В. Циркаль, це не загальновідомі в судочинстві наукові, технічні й практичні знання, отримані внаслідок професійного навчання або роботи за певною спеціальністю особою, залученою як спеціаліст з метою сприяння слідчому чи прокурору в з'ясуванні обставин справи або дачі висновку з питань, для вирішення яких потрібне їх використання [3, с. 22].

На практиці під час проведення СРД, зокрема огляду, у низці випадків необхідними є спеціальні знання з психології, медицини, географії, біології, зоології тощо. 3 огляду на це, визначення спеціальних знань, якими повинен володіти спеціаліст, у контексті ст. 71 КПК України є вужчим за реальний зміст і потребує доповнення, узгодження 3 характеристикою спеціальних знань експерта як спільних за сутністю, а також гармонізації з іншими статтями КПК України (ст. 101 КПК України).

Це засвідчує аналіз й інших статей КПК України. Наприклад, згідно зі ст. 236 КПК України, під час виконання ухвали про дозвіл на обшук житла чи іншого володіння особи 3 метою одержання допомоги $з$ питань, що потребують спеціальних знань, слідчий, прокурор для участі в обшуку має право запросити спеціалістів. Аналогічно в ст. 237 КПК України «для участі в огляді, з метою одержання допомоги 3 питань, що потребують спеціальних знань, слідчий, прокурор може запросити спеціалістів».

Для однозначного тлумачення сутності спеціальних знань доцільно, на нашу думку, доповнити ч. 1 ст. 71 КПК України, у якій визначити, що «спеціалістом у кримінальному провадженні є особа, яка володіє науковими, технічними або іншими спеціальними знаннями та навичками застосування технічних або інших засобів і може надавати консультації під час досудового розслідування й судового розгляду з питань, що потребують відповідних спеціальних знань і навичок».

Запропоновані доповнення підтримали й практичні працівники. Так, на питання, чи доцільним є доповнення ч. 1 ст. 71 КПК України й закріплення в такій редакції: «спеціалістом у кримінальному провадженні $€$ особа, яка володіє науковими, технічними або іншими спеціальними знаннями та навичками...», позитивно відповіли 70\% слідчих.

Емпіричні дані засвідчили, що до проведення СРД під час розслідування насильницького зникнення людини залучали таких спеціалістів: інспектора-криміналіста (81\%), спеціаліста в галузі комп'ютерної техніки (79,8\%), судово-медичного експерта або лікаря (13\%), педагога, психолога (11\%) та ін.

На підставі проведеного дослідження встановлено, що основними напрямами надання спеціалістом допомоги слідчому під час розслідування насильницького зникнення людини є: 
- ознайомлення із сучасними можливостями дослідження речових доказів, слідів насильницького зникнення людини (іншого злочину), виявлених під час проведення СРД та НСРД;

- визначення технічних засобів, які необхідно використовувати, методів і прийомів їх застосування (залежно від обставин зникнення особи; злочину, який учинено);

- допомога в залученні експерта й підготовці матеріалів для його роботи (наприклад, формулювання питань експерту), оцінюванні експертного висновку.

Участь фахівця в галузі медицини під час огляду відіграє важливу роль при розслідуванні насильницького зникнення людини. На місці події в багатьох випадках залишаються сліди крові та інші виділення організму. Правильна їх оцінка спеціалістом - медичним працівником - допомагає змоделювати деякі обставини й обстановку цієї події. За слідами крові спеціаліст - медичний працівник - може дати пояснення слідчому щодо місця вчинення злочину, переміщення тіла потерпілого, розташування його в момент нанесення тілесних пошкоджень тощо. На місці події спеціалістом можуть бути виявлені відбитки рук чи ніг з кров'ю, волосся, частинки слини, речовини біологічного походження тощо. Виявлене допоможе дати відповідь на низку питань, що стосуються факту вчинення злочину. Якщо неможливо залучити до проведення цієї СРД судово-медичного експерта, то слідчий зобов'язаний запросити лікаря. Залежно від характеру злочину слідчий вирішує, якою спеціальністю повинен володіти лікар [4, с. 47]. Наприклад, участь спеціаліста медичного працівника - при проведенні СРД є однією з форм використання медичних знань у розслідуванні насильницького зникнення людини, що розширює можливості слідчого в установленні й дослідженні слідів та обставин учинення злочину. Однак проведене нами анкетування показало, що лише в $17 \%$ кримінальних провадженнях слідчі залучали спеціалістів - медичних працівників або судовомедичних експертів - до участі в СРД.

В окремих випадках кримінальний процесуальний закон зобов'язує слідчого залучити до проведення СРД особу, що володіє спеціальними знаннями. Так, згідно зі ст. 226 КПК України, допит малолітньої або неповнолітньої особи проводять у присутності законного представника, педагога або психолога, а за необхідності - лікаря. Під час проведення СРД за участю малолітньої або неповнолітньої особи забезпечують участь законного представника, педагога або психолога, а за необхідності - лікаря (ст. 227 КПК України) [1].
Окремою формою використання спеціальних знань $є$ залучення стороною кримінального провадження експерта та проведення експертизи [5; 6]. Згідно зі ст. 244 КПК України, якщо для з'ясування обставин, що мають значення для кримінального провадження, необхідні спеціальні знання, сторони кримінального провадження мають право звернутися 3 клопотанням про проведення експертизи до слідчого судді. Експертизу проводять експертна установа, експерт або експерти за дорученням слідчого судді чи суду, наданим за клопотанням сторони кримінального провадження, або якщо для з'ясування обставин, що мають значення для кримінального провадження, необхідні спеціальні знання. Не допускається проведення експертизи для з'ясування питань права (ст. 242 КПК України) [1]. Фактичною підставою для призначення експертизи є потреба в наукових, технічних або інших спеціальних знаннях, які потрібні для вирішення певних питань у кримінальному провадженні. Варто мати на увазі, що до спеціальних не належать загальновідомі й загальнодоступні наукові знання в галузі матеріального та процесуального права, якими повинні володіти слідчі, прокурори, судді. Саме тому закон прямо забороняє проведення експертизи для з'ясування питань права. На неприпустимість ставити експерту правові питання (наприклад, про вину обвинуваченого в смерті потерпілого або заподіянні йому тілесних ушкоджень, про осудність особи, а не про її психічний стан тощо) указує й Постанова Пленуму Верховного Суду України «Про судову експертизу в кримінальних і цивільних справах» від 30 травня 1997 р. № 8 (п. 2). Водночас кримінальнопроцесуальне право передбачає проведення судової правової експертизи в судочинстві України [7, с. 40-41].

Відповідно до ст. 1 Закону України «Про судову експертизу», судова експертиза - це дослідження на основі спеціальних знань у галузі науки, техніки, мистецтва, ремесла тощо об’єктів, явищ і процесів з метою надання висновку з питань, що є або будуть предметом судового розгляду [2].

Обгрунтовано, що найпоширенішою формою застосування спеціальних знань у кримінальних провадженнях, розпочатих у зв'язку з насильницьким зникненням людини, є залучення експерта та проведення експертизи. Зокрема, ідеться про такі судові експертизи (додаток А): дактилоскопічну (81\%), трасологічну (82\%), відео-звукозапису (відеофоноскопічна, фоноскопічна, фонетична) (58\%), судово-біологічну $(48 \%), \quad$ комп'ютернотехнічну (24\%), телекомунікаційних систем 
і засобів (18\%), почеркознавчу (15\%), психіатричну (12\%), портретну (11\%), мікрочастин, матеріалів і речовин (10\%), судово-балістичну (3\%), експертизу холодної зброї ( $2 \%)$, хімічну (2\%), технічну експертизу документів (1\%) тощо. Кількість зазначених експертиз відображає співвідношення слідової інформації, яку вилучали.

Названі експертизи в процесі розслідування цих кримінальних проваджень призначаються залежно від способу вчинення злочину, від слідчої ситуації, що склалася.

Емпіричні дані засвідчують, що однією 3 найпоширеніших є дактилоскопічна експертиза (81\%). Унаслідок іiі проведення серед виявлених слідів папілярних узорів виокремлюють сліди зниклої особи. Завданнями дактилоскопічної експертизи є ідентифікація особи за слідами ї̈ рук, які залишені на місці події. Експертиза слідів рук вирішує й низку неідентифікаційних завдань, пов'язаних із визначенням механізму слідоутворення, особливостями будови руки, яка залишила слід. Сліди рук можна вилучити при дослідженнях листів, аудіо-, відеокасет, оптичних дисків [8, с. 93].

Якщо вчинено вбивство, замасковане під безвісну відсутність особи, після виявлення трупа потерпілого дактилоскопічна експертиза дає можливість ідентифікувати особу за слідами пальців рук. Крім цього, якщо на місці події буде виявлено сліди пальців рук підозрюваного, після перевірки за криміналістичними обліками доцільно призначити дактилоскопічну експертизу [9, с. 102].

У разі виявлення на місці події або поблизу слідів транспортного засобу та за наявності інформації про використання злочинцями певного виду транспорту під час учинення злочину або з метою приховати сліди його вчинення варто призначити $m p a$ сологічну експертизу [10, с. 49]. Завданнями такої експертизи також $є$ ідентифікація людини за слідами (босих ніг, шкарпеток, панчіх, взуття) і встановлення особливостей пересування людини, а також установлення типу, моделі транспортного засобу.

Під час установлення обставин насильницького зникнення людини важливим завданням $є$ визначення походження, механізму утворення слідів і мікрочастинок на місці мешкання, останнього місця перебування, роботи потерпілого. За необхідності здійснюють експертне дослідження грунту, частки якого виявлено під час проведення огляду й обшуку (наприклад, виявлені частини грунту на лопаті, взутті особи).

За виявленими слідами крові може бути призначено низку експертиз. Зокрема, якщо за одними й тими самими слідами крові необхідно встановити механізм їх утворення та групову належність, доцільно спочатку призначити експертизу для встановлення механізму утворення слідів, а потім біологічну експертизу [11, с. 67].

Молекулярно-генетична ідентифікація має низку переваг порівняно з іншими традиційними методами дослідження біологічних слідів людини. Сучасний рівень розвитку ДНК-аналізу засвідчує необхідність використання його результатів під час розшуку безвісно відсутніх осіб і розкриття злочинів за цими фактами [12, с. 45-46; 13, с. 177-178]

Зокрема, збіг групи крові, статі, визначеної за слідами біологічного походження людини (крові, волосся, поту тощо) на місці події та зразками біологічного матеріалу людини, дає підстави для висновку тільки про можливу причетність конкретної підозрюваної особи до вчинення злочину, а під час проведення ДНК-аналізу можна здійснити ідентифікацію з високим ступенем вірогідності, на відміну від інших методів дослідження (наприклад, імунологічних).

Для призначення молекулярно-генетичної експертизи до експертної установи надають вилучені зразки біологічного походження; зразки слідів біологічного походження осіб, що проходять у справі, для порівняння (кров, слина). Вилучення зразків біологічного походження проводять за визначеною КПК України процедурою.

В ухвалі слідчого судді про проведення експертизи (ст. 244 КПК України) дають дозвіл на часткове або повне використання слідів під час проведення досліджень; дозвіл на зміну об'єкта дослідження. Зазначене пов'язано 3 тим, що методи дослідження ДНК є руйнівними й повторне дослідження неможливе.

Якщо після зникнення особи їі родичам або знайомим надходили будь-які листи, записки або телеграми від її імені, доречним $€$ призначення почеркознавчої та авторознавчої експертиз [14, с. 412]. Якщо це рукописний текст, у ньому відобразяться особливості: почерку особи, яка його написала; використаного письмового приладу (ручки, фломастера), барвника (пасти, фарби). Друкований текст передбачає особливості процесу друку й тих пристосувань, які використано [15, с. 38].

Завданнями почеркознавчої експертизи $€$ ідентифікація виконавця рукописного тексту й підписів. Ця експертиза вирішує й діагностичні питання з метою встановлення за почерком незвичних умов виконання рукописів (функціональних і патологічних станів) i зовнішніх (чинників обстановки), а також належність до певної вікової групи. 
Завданнями авторознавчої експертизи в розслідуванні насильницького зникнення людини є ідентифікація автора тексту за його змістом (стиль викладення, граматичні та орфографічні помилки) [16, с. 62]

У ситуації, коли під час огляду чи обшуку виявляють сліди дії вогнепальної зброї, власне зброю, сліди пострілу, необхідно призначити судово-балістичну експертизу. Для дослідження фото-, аудіо- або відеодокументів призначають фототехнічну, фоноскопічну або відеотехнічну експертизи [17, с. 214].

Завданнями фототехнічної експертизи є ідентифікація фотоапаратури за негативами, ідентифікація негативу за позитивами, ідентифікація предметів, приміщень і ділянок місцевості, зображених на знімках (негативах), тощо. Визначають певні види завдань цієї експертизи: ідентифікаційні: ототожнення фотоапаратури за негативами, ототожнення лабораторного устаткування за фотовідбитками тощо; діагностичні: встановлення умов зйомки і виготовлення знімка, особливостей освітлення, чи застосовувалися ретуш, монтаж, які розміри об'єктів і фотознімку, яка відстань між ними тощо [18].

Завданнями відео й фоноскопічної експертизи є встановлення: ідентичності відео,- аудіозапису (оригінальність запису); з'ясування, чи відео-, фонограма є оригіналом чи копією, чи відео-, аудіозапис зроблений на одному й тому ж пристрої, який номер телефону було набрано при фіксації безпосередньо з телефонної лінії, які шуми $€$ на відео-, аудіозапису з подальшим проведенням шумоочищення; відновити дослівний зміст розмови, записаної на відео-, фонограмі; установити, скільки осіб брало участь у розмові (фоноскопічна), з'ясувати, що конкретно говорила та чи інша особа; ідентифікація голосу конкретної особи; установлення параметрів відео-, звукозаписувальної апаратури, з'ясування обстановки, у якій проводився відео-, аудіозапис, установлення його справжності тощо.

Також за допомогою фоноскопічної експертизи можна скласти уявлення про викрадача за записом телефонних переговорів чи за наданою фонограмою; викрити підозрюваного (обвинуваченого) у причетності до вчинення ним викрадення, установивши, що він вів усні переговори з близькими викраденого; отримати доказ того, що саме на цій звукозаписувальній апаратурі, виявленій під час огляду або обшуку, виготовлено касету зі зверненням про передачу викупу тощо [19, с. $144-145]$.

Аудіо аналіз дає можливість визначити (3 деякою ймовірністю) національність того, хто говорить, стать, вік, регіон формування усного мовлення й можливого місця тривалого проживання особи, іï професії, рівень і характер освіти, емоційний стан у момент розмови, психічний і фізичний стан тощо [20, c. 72].

\section{Висновки}

Отже, в умовах набуття злочинною діяльністю нових та особливо небезпечних форм, 3 одного боку, і реформування органів кримінальної юстиції, адаптації законодавства України до європейського - $з$ другого, актуальним є питання аналізу теоретичного підгрунтя та вивчення судово-експертної практики задля виявлення проблемних питань, які існують у сфері експертного забезпечення правосуддя, на підставі цього - розроблення шляхів вирішення цих проблем. Судова експертиза все більше стає затребуваною під час досудового розслідування кримінальних проваджень про насильницьке зникнення людини.

\section{Список використаних джерел:}

1. Кримінальний процесуальний кодекс України : Закон України від 13 квіт. 2012 р / Верховна Рада України. URL: http://zakon3.rada.gov.ua/ laws/show/4651-17КПК.

2. Про судову експертизу : Закон від 25 лютого 1994 р. № 4038-XII / Верховна Рада України. URL: https://zakon.rada.gov.ua/laws/ show/4038-12.

3. Лисиченко В.К., Циркаль В.В. Использование специальных познаний в следственной и судебной практике. Киев : Киев. гос. ун-т им. Т.Г. Шевченко, 1987. 100 с.

4. Галдецька І.Г. Правові та наукові основи використання спеціальних медичних знань при розслідуванні злочинів : дис. ... канд. юрид. наук : 12.00.09. Київ, 2011. 231 с.

5. Романюк Б.В. Участь спеціаліста на стадії досудового слідства : навчальний посібник. Київ : Видавничий будинок «Аванпост-Прим», 2010. 304 c

6. Судові експертизи в процесуальному праві України : навчальний посібник / за заг. ред. О.Г. Рувіна. Київ : Ліра-К, 2019. 424 с.

7. Кравчук О.В., Циганюк Ю.В. Порядок призначення судових експертиз у сфері інтелектуальної власності за новим кримінальним процесуальним кодексом України. Криміналістичний вісник. 2013. № 2 (20). С. 34-45.

8. Пиріг І.В., Бідняк Г.С. Використання спеціальних знань на досудовому розслідуванні : навчальний посібник. Дніпро : Дніпропетровський держ. ун-т внутрішніх справ, 2019. 140 с.

9. Мазурок О.Я. Виявлення, фіксація та вилучення слідів крові під час розслідування фактів безвісного зникнення особи. Криміналістичний вісник. 2015. № 2 (24). С. 99-103. 
10. Кофанов А.В., Волошин О.Г., Літвінова О.В. Трасологічні дослідження : курс лекцій. Київ : Київ. нац. ун-т внутр. справ, 2010. 304 с

11. Гора І.В., Колесник В.А. Криміналістичні експертизи та дослідження, що проводяться у системі правоохоронних органів України : наук.практ. посіб. Київ : Акад. СБУ, 1999. 80 с.

12. Петричук С.В. Особливості призначення та проведення молекулярно-генетичної експертизи. Сучасні криміналістичні експертизи в розслідуванні злочинів : матеріали круглого столу, Київ, 25 лют. 2015 р. Київ : Нац. акад. внутр. справ, 2015. C. $45-48$.

13. Мазурок О.Я.Криміналістичне забезпечення діяльності Національної поліції під час розшуку безвісно відсутніх осіб : дис. ... канд. юрид. наук : 12.00 .09 . Київ, 2018. 255 с.

14. Салтевський М.В. Криміналістика (у сучасному викладі) : підручник. Київ : Кондор, 2005. $588 \mathrm{c}$

15. Методика расследования преступлений, совершаемых на почве национальной или расовой вражды или ненависти : метод. реком. / А.Я. Винников, Н.М. Гиренко, О.Н. Коршунова, А.В. Леухин, Е.Б. Серова ; под общ. ред. О.Н. Коршуновой. Санкт-Петербург, 2002.92 c.

16. Почерковедение и почерковедческая экспертиза : учебник / под ред. В.В. Серегина. Волгоград : Волгоградская академия МВД России, $2007.340 \mathrm{c}$.

17. Гончаренко В.Г., Гора I.В., Будко Т.В. Експертизи у судочинстві України : наук.-практ. посіб. Київ : ЮрінкомІнтер, 2015. 504 с.

18. Щербаковський М.Г. Проведення та використання судових експертиз у кримінальному провадженні : монографія. Харків : В деле, 2015. 560 с.

19. Милюков С.В. К вопросу об идентификационно значимых свойствах человека при установлении личности в ходе раскрытия и расследования преступлений. Вестник криминалистики. 2011. Вып. 1 (37). С. 142-145.

20. Пиріг I.В. Технічне забезпечення експертної діяльності. Криміналістичний вісник. 2015. № 2 (24). C. $70-77$.

Fedir Sokyran, Yevhen Voitovych. Use of special knowledge in the investigation of enforced disappearances

The article clarifies that the use of special knowledge in the investigation of enforced disappearances is carried out in the following forms: involvement of a specialist in the conduct of investigative (search) actions, involvement of a specialist in conducting covert investigative (search) actions, involvement of an expert and examination, providing consultations by a specialist. It was found that an important form of application of special knowledge in criminal proceedings initiated on the fact of enforced disappearance is the involvement of an expert and examination. A special place in the investigation of such crimes belongs to dactyloscopic examination. However, it is advisable to more actively use gene identification examinations whose main task is to identify a particular person on the basis of genetic information contained in biological particles pieces of skin, as well as in fluids - saliva, blood, sweat and examination of telecommunications systems and tools the need to study the in formation contained in the memory of mobile phones, smartphones, including SIM-cards (victim or suspect). It is emphasized that for the purpose of molecular genetic examination to the expert institution provide: withdrawn samples of biological origin; samples of traces of biological origin of persons involved in the case, for comparison (blood, saliva). Withdrawal of samples of biological origin is carried out according to the procedure established by the CPC of Ukraine. It is concluded that in the conditions of acquiring new and especially dangerous forms of criminal activity, on the one hand, and reforming criminal justice bodies, adaptation of Ukrainian legislation to the European one - on the other hand, the analysis of theoretical basis and study of forensic practice is relevant. , which exist in the field of expert support of justice, and on this basis - the development of ways to solve these problems. Forensic examination is becoming increasingly popular during the pre-trial investigation of criminal proceedings on the enforced disappearance of a person.

Key words: enforced disappearance, person, pre-trial investigation, special knowledge, specialist, expert, examination. 